\title{
Public Preferences for Food-Energy-Water Tradeoffs in the Western U.S.
}

\author{
Brent S. Steel *, Erika Allen Wolters and Rebecca L. Warner \\ School of Public Policy, Oregon State University, Corvallis, OR 97331, USA; \\ erika.wolters@oregonstate.edu (E.A.W.); rwarner@oregonstate.edu (R.L.W.) \\ * Correspondence: bsteel@oregonstate.edu; Tel.: 1-(541)-727-2811
}

Received: 24 July 2019; Accepted: 9 September 2019; Published: 23 September 2019

\begin{abstract}
The food-energy-water (FEW) nexus is, by definition, a "wicked problem" in that potential solutions in one sector may inadvertently create perverse effects in another. For example, rapid population growth in conjunction with increasing urbanization will add additional stress to current pressures on the world's FEW resources. Water scarcity will increase challenges in providing plentiful foods, as well as clean, potable water. Water is also critical to energy production-and conversely-energy is needed to deliver clean, safe water. Extant and projected demand for FEW creates an intertwined problem of supply and demand and new policy considerations for managing the nexus. This study examines the FEW policy tradeoff preferences of the public in California, Idaho, Oregon and Washington states, using survey data collected in 2018. More specifically, this study examines the impact of demographic control variables, FEW knowledge, and environmental values and beliefs on hypothetical tradeoffs between FEW policy preferences. Findings suggest that those respondents that believe in human-caused climate change and with higher new ecological paradigm (NEP) scores were more supportive of water quality issues versus hydroelectric energy production, rural solar energy development versus limiting rural solar development for food production, and water quality over food production for a growing population.
\end{abstract}

Keywords: food-energy-water nexus; policy tradeoffs; food policy; energy policy; water policy

\section{Introduction}

Water is required for agricultural produce, energy is required to pump the water from various sources, and again water is used for hydropower to generate electricity (energy). Hence, a vicious circle of water-food-energy is created where one imbalance leads to the deterioration of all the components. However, the global community has addressed each of the components separately, but rarely have they addressed the problems that the three face together because of their close association. [1] (p. 3042)

This quote from Barik et al. [1] illustrates the complexity of food, water and energy (FEW) policy and the historical lack of attention given by policymakers and managers to the FEW nexus, or the point where actions in one sector impacts the others. The interconnectivity between all three nexus components is crucial as it is the foundation "upon which our current civilization depends for social and political stability" [2] (p. 7). Focus on the FEW nexus has raised significant concerns about creating policies that address both individual sectors of the nexus and the integrated nature of FEW. Similarly, research into public preferences concerning FEW policy tradeoffs is limited, yet increasingly important, as climate change effects threaten each of the separate FEW policy domains, but also the integrated nature of FEW policy issues [3].

Political conflict over many public policy issues, such as the FEW nexus, are often framed by the cultural context within which they take place [4-6]. Such cultural contexts can differ significantly 
between regions of the country [6,7]. For example, the relatively liberal (i.e., "blue") Pacific coast states of California, Oregon and Washington are more prone to adopt environmental protection policies when compared to more politically conservative (i.e., "red") states such as Alabama and Mississippi. Moreover, issues embedded in FEW tradeoffs have major implications for a broad range of personal and political values and beliefs [3]. Therefore, to the degree that individual values and beliefs impact FEW policy tradeoffs, we expect FEW tradeoff preferences to vary significantly in accordance with differences in beliefs and values.

In 2019, the world population is 7.3 billion people, but is anticipated to grow to 9.8 billion by 2050 and 11.2 billion by 2100 [8]. As population continues to grow, so will urbanization, which increases the potential for economic development opportunities through "innovation and increased economies of scale" [9] (p. 1). Concurrent with economic growth is an anticipated increased demand for consumer goods and services, prompting further pressures on the "wealth-creating potential of water, energy and land" [10]. Unless consumption patterns change to more sustainable practices, the earth's natural systems may become strained beyond human carrying capacity. This is already evidenced by water scarcity that is currently affecting 2.8 billion people globally [11]. Due to increased demands for water (and changes to water availability as a result of climate change), it is estimated that by 2025, "two-thirds of the world's population may face water shortages" [11] (p. 4).

As the global population continues to increase, climate change has created a perverse feedback cycle resulting in less available and dependable fresh water supplies (needed for energy production and food production), extended periods of drought (challenging food production), and the loss of species critical to both ecosystem health and human consumption, as well as a myriad of other consequences that directly and indirectly affect human health and wellbeing [12]. Consumption patterns in developed countries are unsustainable at current rates, and current production cannot meet the needs and demands of a growing population. Population growth coupled with climate change inherently challenges food, water and energy needs that are the very foundation of human health and wellbeing [12].

Research on public knowledge and attitudes toward FEW nexus policy preferences is limited. Most research to date has focused on the scientific and technical aspects of the FEW nexus and not on public awareness and policy preferences. As Portney et al. [3] - who conducted the first robust analysis of public awareness and attitudes toward the FEW nexus-have stated, " ... to date, social, economic, and policy issues associated with the nexus have largely been under-researched ... there has been very little social science or policy research on any aspect of this nexus" (p. 4). The study presented here extends the discussion on the nexus begun by Portney et al. [3], examining the values, beliefs and knowledge of individuals concerning FEW policy tradeoff preferences in the western states of California, Idaho, Oregon and Washington.

This study begins with a brief overview of values-beliefs-norms theory (VBN), which will be used to analyze the degree to which public attitudes and preferences toward FEW tradeoffs are rooted in fundamental views of the relationships of humans and the environment [13]. In particular, the focus is on identifying the extent to which socio-demographic characteristics, FEW knowledge, and environmental value orientations affect FEW tradeoff preferences. We evaluate these relationships with data collected via surveys from four Western states in the spring of 2018. We conclude with a discussion of the policy implications of the findings.

\section{Values-Beliefs-Norms (VBN) Theory and Correlates of FEW}

Finding which variables demonstrate the potential for stable, consistent actions is critical to formulating public engagement in resource reduction activities. While there are many possible cognitive theories that could be employed in the research topic investigated here, VBN theory has been a popular and useful approach to examine public policy preferences. The VBN theory is a cognitive approach that suggests that individuals will be motivated to engage when values aligned with a 
movement they support are perceived to be threatened. The motivation translates into action if people believe their efforts can help to restore those values [13].

VBN Theory has been used to explain environmental preferences as an outcropping of values that can be measured by Dunlap et al.'s [14] new ecological paradigm (NEP) scale [15-17]. The NEP has been successfully utilized as a scale to assess attitudes, beliefs and values as indicators of a broader endorsement of a worldview that is ecologically centered [18]. These pro-environmental values provide the basis for action when individuals are aware of environmental problems and feel their actions can positively impact the outcome. Therefore, this study uses the VBN as a general frame for examining the impact of values and beliefs on FEW tradeoffs. In addition, various demographic control variables are included in the analyses along with familiarity and knowledge concerning FEW issues. A brief overview of this literature follows.

\subsection{Demographic Factors}

The demographic control variables to be included in the forthcoming multivariate analyses include age, gender, education and income. These control variables are often employed in VBN research involving environmental values, concern and preferences. Concerning age, many researchers have found that younger people are more likely to express environmental concern in comparison to older generations [14,19-22]. Another strong predictor of environmental concern is education level. Many studies have found a positive correlation between higher educational attainment and environmental concern [22-24]. However, research on how age and education might affect positions on FEW tradeoffs has not been conducted to date. If consistent with this previous research, we should find younger and more highly educated people to favor more environmentally oriented FEW tradeoff options.

Gender and income are additional demographic control variables that are included in the forthcoming analyses. While some research suggests that these are less consistent predictors of environmental concern [25], a growing number of studies suggest a correlation (although potentially mild or weak). For example, several studies have found that women are more likely to express environmental concern $[17,21,25,26]$, and that a higher income increases environmental concern $[19,27]$, particularly in countries with overall higher national incomes [27].

\subsection{Knowledge}

Recent research concerning public support for renewable energy technologies is strongly related to levels of policy relevant knowledge. Pierce and Steel [18] found that people with higher levels of environmental and energy technology knowledge were more likely to support the adoption of renewables in comparison to people with lower levels of knowledge. Similarly, O'Connor et al. [28] found that causal knowledge of climate change was a "powerful predictor of behavioral intentions," and that those with higher levels of knowledge are more likely to support government policies to address climate change. However, knowledge not formally obtained, such as through public education programs, also has been shown to predict increased levels of environmental behaviors [29]. Knowledge is also seen as a precondition for concern and efficacy. A study by Milfont [30] found that greater knowledge of climate change was related to an increased concern and a greater sense of self-efficacy in mitigating climate change. In the Portney et al. study [3], various "nexus awareness" indexes were created (water-food, water-energy, and energy-food) and were all found to be associated with FEW policy preferences. Further, awareness of one aspect of the nexus (e.g., food and water) was found to increase awareness of other components of the nexus and increase policy support [3].

\subsection{Environmental Values and Beliefs}

The main focus of the analyses presented in this study is the impact of environmental values and beliefs on FEW tradeoffs. More specifically, the NEP and climate change beliefs are the variables that will be examined. Based on prior research, a pro-NEP position has been found to be a consistent 
indicator of environmental concern and behavior [31-33]. The NEP has been used as a predictor of energy policy preferences [18] and water policy preferences [34,35]. This study will be the first to use the NEP as a potential predictor of FEW policy preferences.

A second variable that will be examined concerns belief in climate change. Belief in climate change has been found to drive the policy preferences of people [36,37]. McCright and Dunlap's [38] research on climate change deniers suggests that this mostly conservative and white group of men " ... are likely to favor protection of the current industrial capitalist order which has historically served them well," which leads to denial because of the threat that climate change "... poses to the industrial capitalist economic system" [38] (p. 1163). This orientation may well impact FEW tradeoff choices made by climate change deniers that would lead to disruption of the status quo.

As noted previously, there are very few studies that examine the publics' awareness and policy support of the FEW nexus. To the best of our knowledge, only Portney et al. [3] have explored this topic in any detail. In that study, the authors set out first to explore a sense of awareness that Americans have about the water-energy-food nexus. Based on their national survey research, they discovered that people who were aware of some nexus elements (e.g., the connection between food and water) were also highly likely to know about other linking elements (e.g., the relationship of water and energy). They also found that levels of nexus awareness show a strong positive correlation with supporting a variety of policy issues that are designed to mitigate problems with nexus connections. The study presented here continues the exploration of the FEW nexus begun by Portney et al.'s research [3]. We will focus our efforts on examining factors that help to predict individuals' FEW tradeoff preferences. Furthermore, we will target specific western states that have had specific regional food, water and energy challenges. Finally, given that this is the first study to examine public FEW tradeoff preferences using hypothetical situations, we will use an exploratory analysis for the relationships between variables, which means that two-tailed statistical tests have been employed.

\section{Methods}

This study was approved by the Oregon State University Institutional Research Board (IRB) on December 6, 2017. Participation in the household survey was completely voluntary. Respondents gave their consent by either completing the physical survey or following a link in order to complete the survey online. Completed surveys were stored on password protected laptops. Student researchers who worked on the project were all IRB certified and worked under the direct supervision of the PI and co-PI's for all phases of the project.

A modified version of Dillman's tailored design method [39] was used in questionnaire format with both an online option and multi-wave mail surveys. Each contacted household was issued the following request for participation: "If available, we would prefer the person, 18 years old or older, who most recently celebrated a birthday to complete the survey." The implementation of the survey was as follows: First, potential respondents were sent a mail postcard announcing the survey with instructions for the online version of the questionnaire; second, the postcard was followed-up with a first class mail survey sent to non-respondents for the online or mail surveys; third, a final first class mail survey was sent to non-respondents encouraging participation. Each mailing contained a copy of the survey, a hand-signed letter by the P.I. and a student researcher encouraging participation in the study, and a business postage prepaid envelope for responses. Data from the online survey indicated that the average respondent took about 8 to 10 minutes to complete the questionnaire.

Participants were selected using a random sample provided by a national sampling company. Random address-based sampling (ABS) using the U.S. Postal Service's computerized delivery sequence file (CDS), was used to generate 4,695 valid residential households for California, Idaho, Oregon and Washington $(\mathrm{CA}=1170, \mathrm{ID}=1175, \mathrm{OR}=1173$ and $\mathrm{WA}=1177)$. The CDS includes more than 135 million residential addresses, which covers nearly all households in the U.S. The survey was conducted during the spring of 2018. 
Response rates were calculated by following the American Association for Public Opinion Research guidelines [40]. The response rates varied only marginally among the four states' citizens, with the highest percentage in Oregon (40.5\%) and the lowest in California (37.2\%) (see Table 1). In terms of the modality of response chosen by participants, most used the mail survey, but there were some differences between the states in the percent using mail versus the online Qualtrics survey. Almost a third of California respondents (31.7\%) used the online response option, in comparison to $24.2 \%$ in Oregon, $19.2 \%$ in Washington, and $18.9 \%$ in Idaho. Analyses were conducted to discern possible demographic and value differences between response modalities, with no significant differences identified in any of the case study states. It should be noted that the Portney et al. [3] study had a response rate of $60 \%$, but that survey was administered by telephone.

Table 1. Survey Response Rates.

\begin{tabular}{lllll}
\hline State & Sample Size & Responses & Response Rate & \% Online Return \\
\hline California & 1170 & 435 & $37.2 \%$ & $31.7 \%$ \\
Idaho & 1175 & 440 & $37.4 \%$ & $18.9 \%$ \\
Oregon & 1173 & 475 & $40.5 \%$ & $24.2 \%$ \\
Washington & 1177 & 454 & $38.6 \%$ & $19.2 \%$ \\
\hline
\end{tabular}

For this study we used 2010 U.S. Census data to assess the demographic representativeness of our sample (see Table 2). We used Census data only for those 18 years and older as this was aligned with our sample restrictions. A comparison of our sample to Census data for all four states revealed that our sample included a slightly older, more affluent, and educated group of adults. This finding is not atypical for survey research [41]. The percent of women respondents was almost identical to the Census estimates for each of the four states.

While this is a good method of comparison for demographic variables, Groves points out that there is a weakness, in that the variables of particular interest to our research (e.g., environmental policy preferences) are not found in an external source such as the census [42]. This means that we are not able to know if the variation that exists in our sample related to food-water-energy policy is representative of the views of adults in our four target states.

Measures for most of the variables used in this study are described in Table 4. In addition to these, we draw from the work of Portney et al. [3] to construct an indicator of environmental knowledge (Quiz). Respondents could have scores ranging from 0 to 5, based on the number of correct responses to the following statements: 1 . Using hydraulic fracturing to remove natural gas from the ground uses significant amounts of water (accurate); 2. Periods of drought can mean that an individual power plant cannot make as much electricity (accurate); 3 . Recycled water cannot be safely used to grow food (inaccurate); 4 . Corn used as ethanol fuel gives cars better gas mileage than gasoline; 5 . Crop irrigation in the U.S. uses more groundwater than all other uses combined (accurate). Response categories included: accurate, inaccurate and don't know. Correct responses were given a 1 and wrong responses and don't know were given a 0 for the additive quiz score.

The New Ecological Paradigm (NEP) used in this study is based on survey participants' responses to six items drawn from the NEP index [14]. Each item asks respondents to give a reaction on a five-point scale, ranging from $1=$ strongly disagree to $5=$ strongly agree. The NEP may be the most cited and employed measure in the social science study of the environment, and one of the most in all of social science in the past three decades [43]. The following six statements have been used in many previous studies and are used in this study [18]: 1 . The balance of nature is very delicate and easily upset by human activities; 2 . Humans have the right to modify the natural environment to suit their needs; 3 . We are approaching the limit of people the earth can support; 4 . The so-called "ecological crisis" facing humankind has been greatly exaggerated; 5 . Plants and animals have as much right as humans to exist; 6 . Humans were meant to rule over the rest of nature. After reverse recoding of items 2,4 , and 6, the responses also were summed across all six items to produce an overall index, 
possible scores on which ranged from 6 to 30, with low scores indicating more human centered (human domination of nature) values and higher scores indicating more pro-ecological (nature for nature's sake) values. The scale has a Cronbach's alpha of 0.766 indicating that respondents were relatively consistent in their responses.

Finally, our indicator for climate change beliefs is constructed from two questions used by the Pew Research Center. First, respondents are asked: "From what you've read and heard, is there solid evidence that the average temperature on earth has been getting warmer over the past decades, or not?" If the response was in the affirmative, a follow-up question was asked: "From what you have heard or read, do scientists generally agree that the earth is getting warmer because of human activity, or do they not generally agree about this?" A dummy variable was constructed using the responses to these two questions where $1=$ there is evidence of global warming and it is human-caused, $0=$ else (do not believe that earth temperature is warming or do not believe there is agreement that warming is human caused).

\section{State Case Studies}

The four states of California, Oregon, Idaho and Washington included in this study all have FEW tradeoff issues that governments and stakeholders are currently engaged with, and are exacerbated by the growing impact of climate change. For example, in California, Liu [44] found that climate change "has direct or indirect effects on sustainability and security of water, energy, and food" in the state (p. 151). One area of tradeoffs identified by Liu that will become increasingly intense in California because of the drive to develop renewable energy "... are land and water use conflicts between biomass for biofuel production with agricultural crops for food production" [44] (p. 152).

Table 2. Survey Response Bias.

\begin{tabular}{|c|c|c|}
\hline \multicolumn{3}{|l|}{ California } \\
\hline Demographic Variable & Survey Sample & Census Estimates 1 \\
\hline Mean Age (Over 18) & 47.7 & 47.1 \\
\hline Median Household Income & $\$ 50,000-\$ 74,999$ (Survey category 6) & $\$ 60,883$ (2006-2010 adjusted average) \\
\hline Gender (Over 18) & Male $51.3 \%$, Female $48.7 \%$ & Male $49.5 \%$, Female $51.5 \%$ \\
\hline Associates Degree or Higher (Over 18) & $40.3 \%$ & $36.7 \%$ \\
\hline \multicolumn{3}{|l|}{ Idaho } \\
\hline Demographic Variable & Survey Sample & Census Estimates $^{1}$ \\
\hline Mean Age (Over 18) & 52.6 & 48.0 \\
\hline Median Household Income & $\$ 50,000-\$ 74,999$ (Survey category 6) & $\$ 46,890$ (2006-2010 adjusted average) \\
\hline Gender (Over 18) & Male $49.9 \%$, Female $50.1 \%$ & Male $50 \%$, Female $50 \%$ \\
\hline Associates Degree or Higher (Over 18) & $42.3 \%$ & $39.1 \%$ \\
\hline \multicolumn{3}{|l|}{ Oregon } \\
\hline Demographic Variable & Survey Sample & Census Estimates ${ }^{1}$ \\
\hline Mean Age (Over 18) & 55.3 & 49.5 \\
\hline Median Household Income & $\$ 50,000-\$ 74,999$ (Survey category 6 ) & $\$ 49,260$ (2006-2010 adjusted average) \\
\hline Gender (Over 18) & $48.7 \%$ Male, $51.3 \%$ Female & $48.4 \%$ Male, $51.6 \%$ Female \\
\hline Associates Degree or Higher (Over 18) & $38.1 \%$ & $35.0 \%$ \\
\hline \multicolumn{3}{|l|}{ Washington: } \\
\hline Demographic Variable & Survey Sample & Census Estimates ${ }^{1}$ \\
\hline Mean Age (Over 18) & 50.3 & 48.5 \\
\hline Median Household Income & $\$ 50,000-\$ 74,999$ (Survey category 6) & $\$ 57,224$ (2006-2010 adjusted average) \\
\hline Gender (Over 18) & $48.3 \%$ Male, $51.7 \%$ Female & $48.7 \%$ Male, $51.3 \%$ Female \\
\hline Associates Degree or Higher (Over 18) & $44.8 \%$ & $38.8 \%$ \\
\hline
\end{tabular}

${ }^{1}$ Data obtained from the U.S. 2010 American Community Survey Public Use Microdata Sample.

Similarly, in Oregon, solar farm development on high value agricultural lands in the Willamette Valley has led to conflict between developers, farmers and environmentalists. The conflict has 
culminated with the Willamette Valley counties Marion, Yamhill and Polk placing moratoriums on future solar farm development. According to observers of the debate, "proponents of solar power say the draft rules (moratoriums) would undermine Oregon's energy projects and climate change will negatively affect agriculture in the state more than solar development" [45] (p. 1). Opponents of solar development on agricultural land conversely argue, "we see a threat to high-value farmland ... in my experience, solar arrays are another of these uses that are chewing up Oregon's prime farmland" [45] (p. 1). Idaho and Washington also have such tradeoffs in the FEW nexus, which will increasingly necessitate a more holistic approach to policy and management to mitigate climate change effects. For example, all four of the states have water quality and quantity concerns regarding endangered anadromous fisheries due to agricultural runoff, in addition to hydroelectric dams for energy that also cause fisheries habitat problems [46].

Three of the case study states are leaders in climate change policy and are potentially "best case" scenarios where "... long-term solutions based on socio-cultural, economic and environmental and aesthetic objectives" may be identified for future FEW nexus planning [47]. The Governors of California, Oregon and Washington are members of the U.S. Climate Alliance and have been involved in the Governors' Global Climate Summits co-hosted by the United Nations Environmental Programme (UNEP). They were also signatories to the 2003 West Coast Governors' Global Warming Initiative as well as the 2013 Pacific Coast Action Plan on Climate and Energy, which included strong public commitments to reduce greenhouse gas emissions. Central to these initiatives was a recognition that citizens play a critical role in bringing about change, both through their personal energy use behaviors, as well as their participation in state and local policy processes. Home-grown environmental movements in all three states provide clear evidence that citizens are aware of their state's environmental challenges and want to participate in a response to them [18].

In addition to California, Oregon and Washington, we include Idaho as a control comparison. While it is also in the western region, and borders Washington and Oregon, Idaho has a much less aggressive approach in adopting and promoting climate change policies. The state has a more conservative political culture, and its governor did not sign on to the coastal states' action plan.

\section{Findings}

A series of FEW tradeoff questions were developed for use in the survey based on current issues in the case study states. The introductory question used for the tradeoff issues was as follows: “In recent years there has been considerable attention to tradeoffs between food production, water resources and energy supplies. We are interested in your views of what should be done in cases where those impacts are likely to occur" (see Table 3). Respondents were then provided different FEW tradeoff scenarios that ask for which of two policy approaches (X vs. Y) they were more likely to agree with. Respondents could also report that they were neutral. The three scenarios set up an energy versus water tradeoff, an energy versus food tradeoff, and a food versus water tradeoff. Respondents' tradeoff preferences were then coded as: $1=$ strongly agree with Policy $X, 2=$ agree with Policy $X, 3=$ neutral, $4=$ agree with Policy Y, and 5 = strongly agree with Policy Y. Pierce and Steel [18] successfully used a similar approach to assess tradeoff preferences between renewable energy siting and local environmental concerns. 
Table 3. Frequencies for Food-Energy-Water (FEW) Tradeoffs.

Question: In recent years there has been considerable attention to tradeoffs between food production, water resources and energy supplies. We are interested in your views of what should be done in cases where those impacts are likely to occur. Please circle the number in each case that best represents your opinion.

\begin{tabular}{|c|c|c|c|}
\hline \multirow[t]{2}{*}{ A } & \multicolumn{2}{|c|}{$\begin{array}{l}\text { Develop more hydroelectric dams for energy } \\
\text { independence. }\end{array}$} & \multirow{2}{*}{$\begin{array}{l}\text { Limit hydroelectric dams to promote water } \\
\text { quality and habitat for salmon and other } \\
\text { aquatic species. } \\
\text { Agree and Strongly Agree }\end{array}$} \\
\hline & $\begin{array}{l}\text { Agree and Strongly } \\
\text { Agree }\end{array}$ & Neutral & \\
\hline & Percent & Percent & Percent \\
\hline CA & 36.7 & 24.2 & 39.1 \\
\hline ID & 36.2 & 19.5 & 44.4 \\
\hline OR & 17.1 & 34.6 & 48.3 \\
\hline \multirow[t]{2}{*}{ WA } & 22.4 & 30.7 & 46.9 \\
\hline & \multicolumn{3}{|c|}{$\mathrm{N}=1764 ;$ Chi-square $=73.45, p=0.000$} \\
\hline \multirow[t]{3}{*}{ B. } & \multicolumn{2}{|c|}{$\begin{array}{l}\text { Expand rural solar farms for energy } \\
\text { independence. }\end{array}$} & $\begin{array}{l}\text { Limit the expansion of rural solar farms to } \\
\text { maintain land for agriculture. }\end{array}$ \\
\hline & $\begin{array}{l}\text { Agree and Strongly } \\
\text { Agree }\end{array}$ & Neutral & Agree and Strongly Agree \\
\hline & Percent & Percent & Percent \\
\hline CA & 43.4 & 32.9 & 23.8 \\
\hline ID & 47.2 & 35.2 & 17.6 \\
\hline OR & 48.6 & 24.4 & 27.0 \\
\hline \multirow[t]{2}{*}{ WA } & 48.0 & 27.0 & 25.0 \\
\hline & \multicolumn{3}{|c|}{$\mathrm{N}=1758 ;$ Chi-square $=21.91, p=0.001$} \\
\hline \multirow[t]{2}{*}{ C. } & \multicolumn{2}{|c|}{$\begin{array}{l}\text { Increase the use of water intensive plants (e.g., } \\
\text { rice) to feed a growing population. }\end{array}$} & $\begin{array}{l}\text { Reduce the use of water intensive plants to } \\
\text { increase access to safe drinking water and } \\
\text { sanitation. }\end{array}$ \\
\hline & $\begin{array}{l}\text { Agree and Strongly } \\
\text { Agree }\end{array}$ & Neutral & Agree and Strongly Agree \\
\hline & Percent & Percent & Percent \\
\hline CA & 13.3 & 41.7 & 45.0 \\
\hline ID & 17.0 & 47.2 & 35.8 \\
\hline OR & 10.3 & 40.0 & 49.7 \\
\hline \multirow[t]{2}{*}{ WA } & 5.6 & 42.2 & 52.2 \\
\hline & \multicolumn{3}{|c|}{$\mathrm{N}=1772 ;$ Chi-square $=44.67, p=0.000$} \\
\hline
\end{tabular}

The first FEW tradeoff issue (energy-water) in Table 3 asked respondents whether more hydroelectric dams should be developed for energy independence versus limiting hydroelectric dams to promote water quality and habitat for salmon and other aquatic species. The distribution of responses was slightly skewed toward preferring the latter statement of limiting dams for water quality and habitat for Idaho, Oregon and Washington, with more than $40 \%$ of respondents agreeing or strongly agreeing with the statement. However, California had a nearly equal balance between both options, with $36.7 \%$ agreeing with more dam development and $39.1 \%$ favoring limiting dams. Oregon and Washington had the lowest percentage of respondents favoring the development of dams and had the highest number of respondents at $17.1 \%$ and $22.4 \%$, respectively. California respondents' support of dam development may well be attributed to a history of power outages and warnings by utilities that future power shortages are likely, in addition to recurring drought and water shortages [48,49]. Idaho also had a higher percentage of respondents supporting dam development when compared to Oregon and Washington, but while they do not have energy shortage issues as in California, Idaho has had a history of drought that may be a partial explanation [50]. All four of the case study states have had 
long and continuing issues with declining salmon runs, due to water quality and quantity and habitat issues due to hydroelectric dams that may be contributing to skewed responses for limiting dams.

The second FEW tradeoff (energy-food) weighed expanding rural solar farms for energy independence against limiting the expansion of rural solar farms to maintain land for agriculture. The preferences for all four states leaned toward expanding solar farms for energy dependence, with more than $40 \%$ of respondents agreeing or strongly agreeing with this position. Oregonians had the highest percent in agreement at $48.6 \%$, while the lowest support of this statement was found among California residents at $43.4 \%$. Oregon-where this is a currently a significant policy issue in the Willamette Valley—had a slightly higher percentage of respondents agreeing to limit solar farms on agricultural land compared to other states. As with the previous tradeoff issue, a large percentage of respondents were neutral on the issue, ranging from $24.4 \%$ in Oregon to $35.2 \%$ in Idaho.

The third tradeoff question included in this study addressed the food-water nexus. Respondents were asked if there should be an increased use of water intensive plants (e.g., rice) to feed a growing population versus reducing the use of water intensive plants to increase access to safe drinking water and sanitation. This FEW tradeoff generated a large percentage of neutral responses in each state, ranging from $40.0 \%$ in Oregon to $47.2 \%$ in Idaho. However, the remaining respondents who did take a position on the issue preferred reducing the use of water intensive plants to increase access to safe drinking water and sanitation. Over $50 \%$ of Washington respondents favored reducing the use of water intensive plants, compared to $49.7 \%$ of Oregonians, $45.0 \%$ of Californians, and $35.8 \%$ of Idaho respondents.

In summary, there were high percentages of respondents that were neutral on all three tradeoffs, suggesting several different explanations. First, respondents may not have thought much about the tradeoffs. Second, respondents may not have had sufficient information to come to a tradeoff preference. Third, respondents may have felt that the policy was not appropriate for the tradeoff. However, for those that took a position there appears to be some environmental concern aspect to the results, with responses leaning slightly more toward limiting dams for water quality and habitat versus energy production, expanding rural solar farms (renewable energy) versus maintaining land for agriculture, and reducing water intensive plant production versus increasing water intensive plants for food production.

\section{Multivariate Analyses}

As discussed above, understanding issues related to the nexus and views about how to address nexus concerns can be affected by a variety factors including, but not limited to, demographic factors, knowledge, and environmental values and beliefs. Our primary independent and control variables, coding information, and measures of central tendency are displayed in Table 4. The demographic control variables include age, gender, education and household income. The knowledge variables include self-assessed awareness of the term food-water-energy-nexus, and an additional five question quiz on FEW issues. The indicators used to assess environmental values and beliefs include a revised version of Dunlap et al.'s new ecological paradigm [14], and a belief in climate change variable.

Mean scores for the demographic control variables indicated that the average age of respondents is 51.6 years, with $50.4 \%$ women, a mean score of 4.80 for education that falls in the "some college" to "college" degree survey response categories, and a mean score of 5.88 for income, which is close to the survey response category of $\$ 50,000$ to $\$ 74,999$. The self-assessment of knowledge question "familiar" had a mean score of 1.71, which is just below the response category of 2 on a 4-point scale ("somewhat familiar"). The mean FEW quiz score was 2.56 (total of 5 items) meaning that respondents answered about half of the quiz items correctly. The mean score for the NEP was 20.73, which is slightly skewed toward the high end of the index, once again not surprising given most respondents are from the three west coast states. Concerning the climate change dummy variable, 61 percent of respondents believed that climate change exists and is caused by humans. Finally, state dummy variables were included in 
the forthcoming multivariate analyses (all combinations rotated), but only the Idaho dummy variable generated significant results, therefore is included in the forthcoming models.

Table 4. Independent and Control Variables.

\begin{tabular}{|c|c|c|}
\hline Variable Name & Variable Description & Mean (SD) \\
\hline Age & $\begin{array}{l}\text { Age in years } \\
\text { (range }=18 \text { to } 98)\end{array}$ & $\begin{array}{l}\text { Mean }=51.6 \\
\mathrm{SD}=16.83 \\
\mathrm{n}=1796\end{array}$ \\
\hline Gender & $\begin{array}{l}\text { Gender dummy variable } \\
(1=\text { female, } 0=\text { male })\end{array}$ & $\begin{array}{l}\text { Mean }=0.504 \\
\mathrm{n}=1787\end{array}$ \\
\hline Education & $\begin{array}{l}\text { Formal educational attainment } \\
(1=\text { less than high school to } 8=\text { postgraduate degree })\end{array}$ & $\begin{array}{l}\text { Mean }=4.80 \\
\mathrm{SD}=1.46 \\
\mathrm{n}=1798\end{array}$ \\
\hline Income & $\begin{array}{l}\text { Household income before taxes in } 2017 \\
(1=\text { less than } \$ 10,000 \text { to } 10=\$ 200,000 \text { or more })\end{array}$ & $\begin{array}{l}\text { Mean }=5.88 \\
\mathrm{SD}=1.80 \\
\mathrm{n}=1772\end{array}$ \\
\hline Familiar & $\begin{array}{l}\text { Level of self-assessed familiarity with the term } \\
\text { food-water-energy nexus } \\
\text { ( } 1=\text { not familiar at all to } 4=\text { very familiar) }\end{array}$ & $\begin{array}{l}\text { Mean }=1.71 \\
\mathrm{SD}=0.929 \\
\mathrm{n}=1790\end{array}$ \\
\hline Quiz & $\begin{array}{l}\text { FEW quiz score } \\
(0=\text { no correct answers to } 5=\text { five correct answers })\end{array}$ & $\begin{array}{l}\text { Mean }=2.56 \\
\mathrm{SD}=1.38 \\
\mathrm{n}=1800\end{array}$ \\
\hline NEP & $\begin{array}{l}\text { New ecological paradigm } \\
(6=\text { low level of support to } 30 \text { high level of support })\end{array}$ & $\begin{array}{l}\text { Mean }=20.73 \\
\mathrm{SD}=5.43 \\
\mathrm{n}=1782\end{array}$ \\
\hline Climate Chg. & $\begin{array}{l}\text { Climate change dummy variable } \\
(1=\text { Climate change exists and is human-caused, } 0=\text { other })\end{array}$ & $\begin{array}{l}\text { Mean }=0.610 \\
\mathrm{n}=1804\end{array}$ \\
\hline Idaho & $\begin{array}{l}\text { Idaho dummy variable } \\
(1=\text { Idaho, } 0=\text { else })\end{array}$ & $\begin{array}{l}\text { Mean }=0.244 \\
\mathrm{n}=1804\end{array}$ \\
\hline
\end{tabular}

Analyses of our tradeoff questions were a challenge. Respondents were asked to choose between two discrete hypothetical options versus placing themselves on a scale from low to high for one option. Without the possibility of being neutral (which received quite a bit of support) we could just dichotomize the dependent variable into support for one option or the other. With the large number of neutral responses, coding was less straightforward. Therefore, we opted to create two separate dichotomous dependent variables for each tradeoff question. We did consider using multinomial logistic regression, however our dependent variables were not uni-dimensional in structure. Rather our measures provided discrete options as responses that could not be clearly ranked. Therefore, we analyzed the data using binary logistic regression models. In the forthcoming models, we show which variables were consistent in their relationship (e.g., does education significantly increase support for option A and significantly decrease the support for option B). In Table 5 we begin with the energy-water tradeoff. In the first model, we gave respondents a code of 1 if they agreed or strongly agreed with the statement to develop more hydroelectric dams for energy independence and 0 otherwise. The second model coded at 1 those who agreed or strongly agreed with the other option (limiting dams to promote water quality). For the two logistic regression models presented in Table 5, the Chi-square statistic is statistically significant for both models indicating a relatively good fit overall. The Nagelkerke $\mathrm{R}^{2}$ is 0.293 for the "develop hydroelectric dams" tradeoff option and 0.148 for the "limit hydroelectric dams" option. 
Table 5. Logistic Regression Estimates for Energy-Water Tradeoffs.

\begin{tabular}{|c|c|c|}
\hline & $\begin{array}{l}\text { Develop more Hydroelectric } \\
\text { Dams for Energy Independence a }\end{array}$ & $\begin{array}{l}\text { Limit hydroelectric Dams to Promote } \\
\text { Water Quality and Habitat for Salmon } \\
\text { and Other Aquatic Species }{ }^{b}\end{array}$ \\
\hline & $\begin{array}{l}\text { Coefficient } \\
\text { (S.E.) } \\
\text { Exp(B) }\end{array}$ & $\begin{array}{l}\text { Coefficient } \\
\text { (S.E.) } \\
\text { Exp(B) }\end{array}$ \\
\hline Age & $\begin{array}{l}-0.023^{* * *} \\
(0.004) \\
0.977 \\
-0.193\end{array}$ & $\begin{array}{l}0.005 \\
(0.003) \\
1.005 \\
0.382 * * *\end{array}$ \\
\hline Gender & $\begin{array}{l}(0.127) \\
0.824 \\
0.033\end{array}$ & $\begin{array}{l}(0.105) \\
1.466 \\
0.085 *\end{array}$ \\
\hline Education & $\begin{array}{l}(0.046) \\
1.034 \\
0.103 \text { ** }\end{array}$ & $\begin{array}{l}(0.038) \\
1.029 \\
0.29\end{array}$ \\
\hline Income & $\begin{array}{l}(0.038) \\
1.108 \\
0.119\end{array}$ & $\begin{array}{l}(0.031) \\
1.115 \\
-135 *\end{array}$ \\
\hline Familiar & $\begin{array}{l}(0.066) \\
1.126 \\
0.154 \text { ** }\end{array}$ & $\begin{array}{l}(0.059) \\
0.874 \\
0.119 * *\end{array}$ \\
\hline Quiz & $\begin{array}{l}(0.049) \\
1.167 \\
-0.142 \text { **** }\end{array}$ & $\begin{array}{l}(0.040) \\
1.126 \\
0.043 \text { *** }\end{array}$ \\
\hline NEP & $\begin{array}{l}(0.013) \\
0.867 \\
-0.959 * * *\end{array}$ & $\begin{array}{l}(0.012) \\
1.043 \\
0.880 \text { *** }\end{array}$ \\
\hline Climate Chg. & $\begin{array}{l}(0.154) \\
0.383\end{array}$ & $\begin{array}{l}(0.132) \\
2.412\end{array}$ \\
\hline Idaho & $\begin{array}{l}0.307^{*} \\
(0.139) \\
1.359\end{array}$ & $\begin{array}{l}0.158 \\
(0.124) \\
1.171\end{array}$ \\
\hline $\mathrm{n}=$ & 1732 & 1732 \\
\hline Chi-square $=$ & $391.794 * * *$ & $385.794 * * *$ \\
\hline Percent correctly predicted $=$ & $81.5 \%$ & $64.5 \%$ \\
\hline Nagelkerke R2 & 0.293 & 0.148 \\
\hline
\end{tabular}

Each of the demographic control variables was significant in at least one of the models. Age had a negative and statistically significant impact for the first model, with younger respondents preferring to disagree to develop more hydroelectric dams when compared to older respondents. Gender was significant for the second model, with women being more likely than men to agree with limiting hydroelectric dams to promote water quality. Education was statistically significant and positive for the limit hydroelectric dams tradeoff option, with the more highly educated agreeing with the option, as compared to respondents with lower levels of education. Income was significant and positive in the first model, with higher income respondents more likely to agree with developing hydroelectric dams than lower income respondents.

Each of the knowledge indicators produced a significant result in at least one of the models. The quiz had a significant and positive impact for both tradeoff options, with respondents that attained a higher quiz score agreeing both to developing more hydroelectric dams and wanting to limit dams to promote water quality. We conducted a bivariate analysis between the quiz indicator and this specific tradeoff and found that those respondents with lower scores were most likely to be neutral, while those with higher scores would demonstrate a bimodal distribution-i.e., they were more likely to have an opinion on the tradeoff. For the self-assessed familiarity variable, there was a significant and negative impact on limiting hydroelectric dams development. Those respondents who considered themselves 
less familiar with FEW preferred limiting hydroelectric dam development, while those that considered themselves more familiar were less likely to agree with this option.

For the environmental values and beliefs variables, which were the main focus of the analyses, the NEP and climate change variables had statistically significant effects in both models. Those with higher NEP scores were more likely to agree with limiting hydroelectric dams to promote water quality and habitat, and less likely to agree with developing hydroelectric dams for energy independence, when compared to respondents with lower NEP scores. Similarly, those respondents that believed that the earth is getting warmer because of human activity were less likely to agree with developing hydroelectric dams, but more likely to agree with limiting hydroelectric dams than those who did not believe that the earth is getting warmer, or not getting warmer because of human activity.

Finally, when using the first model, respondents in Idaho were much more likely to support the building of dams for energy independence compared to those in other states. As noted previously, other state comparisons were statistically insignificant.

Table 6 presents results for the energy-food tradeoff question with the options of "expanding rural solar farms for energy independence" versus "limit the expansion of rural solar farms to maintain land for agriculture." The first model in the table is a dummy variable, with 1 being in agreement with the tradeoff option to expand rural solar farms and 0 is otherwise, and the second model has 1 as being in agreement with limiting the expansion of rural solar farms and 0 is otherwise. As with the models in Table 5, the Chi-square statistic is significant for both models and the Nagelkerke $\mathrm{R}^{2}$ is 0.105 for the first model and 0.045 for the second model.

For the socio-demographic variables included in each model age, gender and income had a statistically significant impact in at least one model each, while education did not produce significant results. The coefficient for age is negative and significant for the expanding rural farms model, with younger respondents more likely to agree with expanding rural solar farms than older respondents. Age was not significant for the second model. The dummy variable for gender was significant and negative for the first model, with women less likely to support expansion of solar farms when compared to men, who were more supportive. Income had a statistically significant effect in both models. Higher income respondents were more likely to agree with expanding rural solar farms than lower income respondents, while lower income respondents were more likely to agree with limiting rural solar farms to maintain land for agriculture.

For the two knowledge indicators, the familiarity variable had a statistically significant impact in both models, while the quiz variable was not significant in either model. Those respondents that considered themselves less familiar with FEW issues were significantly less likely to support rural solar farm development compared to those who considered themselves more familiar. The coefficient in the second model was positive, indicating that those considering themselves more familiar with FEW issues were more likely to agree with limiting the expansion of rural solar farms than those considering themselves less informed.

Finally, for the environmental value and belief indicators included in the models, the NEP had a significant effect in the first model and climate change beliefs had a significant effect in both models. The NEP had a negative and significant effect in the first model, with respondents with lower scores more in favor of expanding rural solar farms than those with higher scores. This result was somewhat unexpected, as we thought that those with stronger environmental values would prefer expanding solar energy. However, the impact of climate change beliefs had a significant effect in both models, with those respondents who believed in human-caused global warming agreeing with expanding rural solar farms in the first model, and being more likely to disagree with limiting solar farm expansion to maintain land for agriculture in the second model.

Again, respondents in Idaho showed some differences from those living in OR, WA or CA. Idahoans were much less likely to show support for limiting rural solar farms to maintain land for agriculture than individuals in other states. 
Table 6. Logistic Regression Estimates for Energy-Food Tradeoffs.

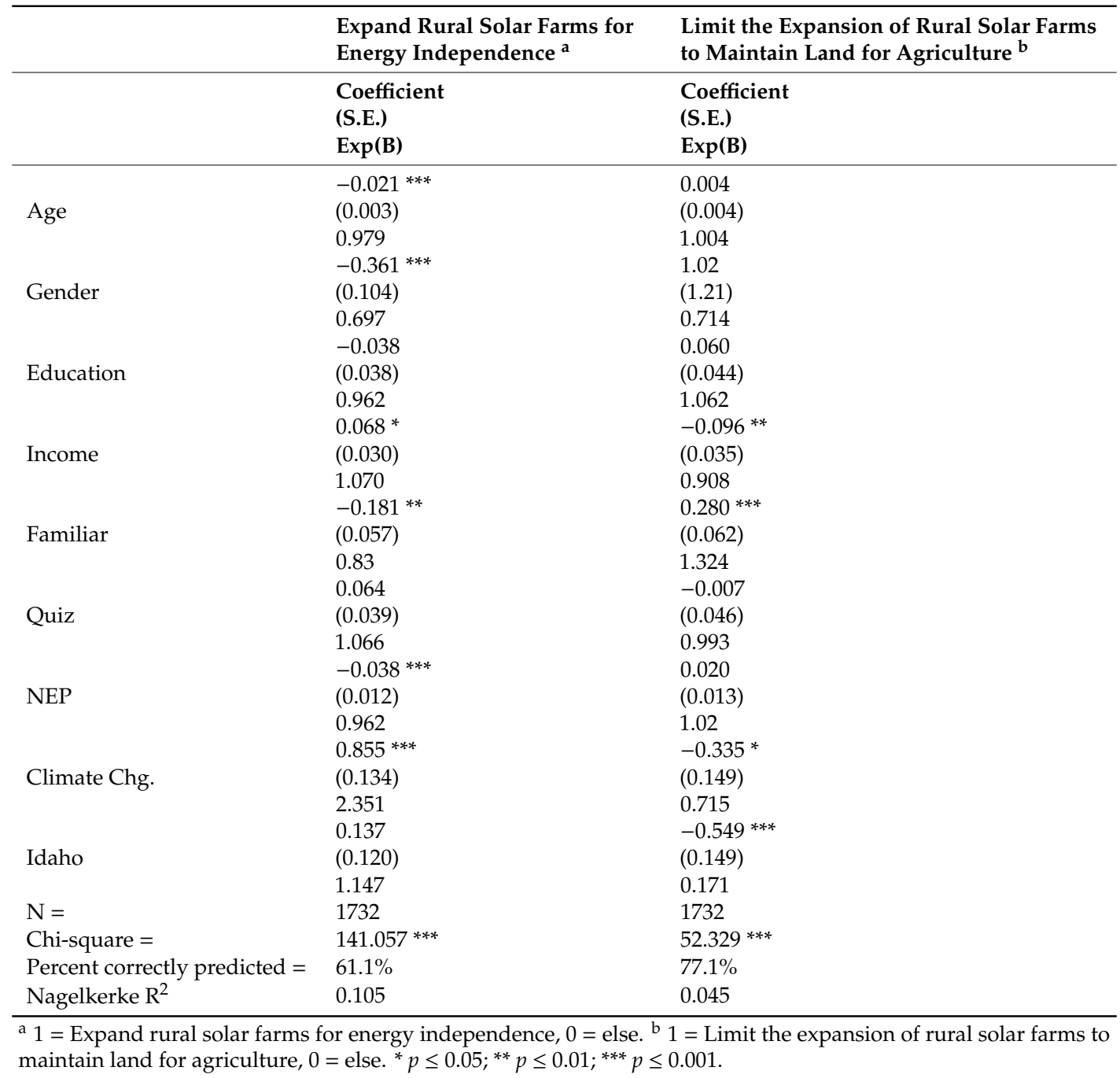

The third and final hypothetical FEW tradeoff (food-water) examined in this study concerns "increase the use of water intensive plants (e.g., rice) to feed a growing population" versus "reduce the use of water intensive plants to increase access to safe drinking water and sanitation." The results for the two logistic regression models are displayed in Table 7. For the four demographic control variables included, we found that age, gender, education and income have statistically significant results for the second model concerning reducing the use of water intensive plants. Only income had a statistically significant effect in the first model.

Younger respondents were more likely to agree with reducing the use of water intensive plants when compared to older respondents. The coefficient for gender was positive in the first model and negative for the second model. Men were more likely than women to agree with reducing the use of water intensive plants to increase access to safe drinking water and sanitation. Both education and income had positive and statistically significant effects for the second model. Those respondents with higher levels of education and income were more likely to agree with reducing the use of water intensive plants to increase access to safe water, when compared to those respondents with lower levels of education and income. Income was significant and negative in the first model, with lower income respondents more likely to agree with increasing the use of water intensive plants when compared to higher income respondents.

The two knowledge indicators only had statistically significant results for the model concerning reducing the use of water intensive plants. Both coefficients were positive, indicating that those who 
considered themselves familiar with FEW issues were more likely to agree with this option than those respondents who considered themselves less familiar. Similarly, those respondents with higher FEWE quiz scores were significantly more likely to agree with this tradeoff than those respondents with lower scores.

For the environmental value and belief indicators, the NEP and climate change variables had statistically significant effects in each model. In the first model, those respondents with lower NEP scores were more likely than those with higher NEP scores to agree with increasing the use of water intensive plants to feed a growing population. In the second model, respondents with higher NEP scores were significantly more likely than those with lower scores to agree with reducing the use of water intensive plants to increase access to safe drinking water. The climate change variable exhibits a similar pattern to the NEP, with those respondents believing the earth is getting warmer because of human activity being more likely to agree than others, to reducing the use of water intensive plants and less likely to agree with increasing the use of water intensive plants.

Table 7. Logistic Regression Estimates for Food-Water Tradeoffs.

\begin{tabular}{|c|c|c|}
\hline & $\begin{array}{l}\text { Increase the Use of Water } \\
\text { Intensive Plants (e.g., Rice) to } \\
\text { Feed a Growing Population }{ }^{\text {a }}\end{array}$ & $\begin{array}{l}\text { Reduce the Use of Water Intensive } \\
\text { Plants to Increase Access to Safe } \\
\text { Drinking Water and Sanitation } b\end{array}$ \\
\hline & $\begin{array}{l}\text { Coefficient } \\
\text { (S.E.) } \\
\text { Exp(B) }\end{array}$ & $\begin{array}{l}\text { Coefficient } \\
\text { (S.E.) } \\
\text { Exp(B) }\end{array}$ \\
\hline Age & $\begin{array}{l}0.007 \\
(0.005) \\
1.007 \\
0.030\end{array}$ & $\begin{array}{l}-0.007 * \\
(0.003) \\
0.993 \\
-0.314 * *\end{array}$ \\
\hline Gender & $\begin{array}{l}(0.177) \\
1.031 \\
-0.109\end{array}$ & $\begin{array}{l}-0.014 \\
(0.110) \\
0.730 \\
0.092 *\end{array}$ \\
\hline Education & $\begin{array}{l}(0.065) \\
0.897 \\
-0.109 *\end{array}$ & $\begin{array}{l}(0.040) \\
1.096 \\
0.136^{* * *}\end{array}$ \\
\hline Income & $\begin{array}{l}(0.050) \\
0.897 \\
-0.050\end{array}$ & $\begin{array}{l}(0.032) \\
1.146 \\
0.129 *\end{array}$ \\
\hline Familiar & $\begin{array}{l}(0.094) \\
0.951 \\
-0.013\end{array}$ & $\begin{array}{l}(0.060) \\
1.137 \\
0.081 *\end{array}$ \\
\hline Quiz & $\begin{array}{l}(0.066) \\
0.987 \\
-0.110^{* * *}\end{array}$ & $\begin{array}{l}(0.049) \\
1.179 \\
0.118^{* * *}\end{array}$ \\
\hline NEP & $\begin{array}{l}(0.017) \\
0.896 \\
-1.197 * * *\end{array}$ & $\begin{array}{l}(0.013) \\
1.126 \\
0.472 \text { *** }\end{array}$ \\
\hline Climate Chg. & $\begin{array}{l}(0.158) \\
0.378 \\
0.377 \text { * }\end{array}$ & $\begin{array}{l}(0.132) \\
1.603 \\
-0.326 *\end{array}$ \\
\hline Idaho & $\begin{array}{l}(0.179) \\
1.458\end{array}$ & $\begin{array}{l}(0.128) \\
0.722\end{array}$ \\
\hline $\mathrm{n}=$ & 1732 & 1732 \\
\hline Chi-square $=$ & $229.826^{* * *}$ & $316.222 * * *$ \\
\hline Percent correctly predicted $=$ & $88.9 \%$ & $68.8 \%$ \\
\hline Nagelkerke $\mathrm{R}^{2}$ & 0.247 & 0.223 \\
\hline
\end{tabular}

As with our other tradeoffs, residents in Idaho differed in their preferences in comparison to those in CA, OR or WA. Here we found that Idahoans were much more supportive of increasing the use of water intensive plants to feed a growing population, and were less supportive of reducing the use of water intensive plans to increase access to safe drinking water and sanitation. 


\section{Discussion}

This study has examined the impact of demographic characteristics, FEW knowledge indicators, political ideology, and environmental values as measured by the NEP and climate change beliefs on hypothetical tradeoffs between FEW policy preferences. It should be noted that people may respond differently if confronted with an actual tradeoff that affects them and their families personally, and that FEW tradeoffs may be much more complex and nuanced than what has been presented in the survey. That being said, some of the findings from the multivariate analyses warrant further discussion.

While the demographic control variables were not the center of the analyses conducted in this study, there were some interesting findings. Age and gender had statistically significant effects for three models each, education was significant in two models, and income was significant in five of the six models. Concerning age, when compared to older respondents, younger respondents were less likely to agree with developing more hydroelectric dams for energy independence, less likely to expand rural solar farms, and less likely to agree with reducing water intensive plants to increase access to safe drinking water. It is hard to discern an underlying pattern to these results.

Gender also had somewhat of a mixed impact on the proposed tradeoffs, with women respondents more likely to agree with limiting hydroelectric dams to promote water quality and habitat, less likely to agree with expanding solar farms for energy independence, and less likely to agree with reducing the use of water intensive plants. The previous literature review suggests that women are more environmentally orientated than men on some issues, which we found concerning the development of dams, where many environmentalists and public agencies in the Western states have suggested changes for fisheries habitat reasons [51,52]. This result is also consistent with previous survey research conducted in the U.S. Pacific Northwest [53]. However, the other two tradeoffs are more difficult to explain.

The literature also suggests that education is an important factor in shaping the environmental orientations of people. For the FEW tradeoff options presented in this study, education was only statistically significant in two models (in different tradeoffs). When compared to respondents with lower levels of education, the more highly educated were more likely to agree to limiting hydroelectric dams to promote water quality and to reduce the use of water intensive plants to increase access to safe drinking water-both pro-water and environmentally oriented options for the FEW tradeoffs, as the literature suggests.

Household income was statistically significant in five of the models. The literature cited previously suggests that income has mixed effects on environmental attitudes and preferences. For the tradeoff questions, households with higher levels of income were more likely to agree to develop hydroelectric dams for energy independence, to expand rural solar farm development, and to agree with reducing water intensive plants for water quality and habitat. In general, higher income respondents were more pro-energy for two tradeoffs and pro-water for the third tradeoff.

Concerning the two knowledge indicators included in the multivariate analyses, the measure of self-assessed FEW familiarity was significant in four models and FEW quiz was significant in three models. Those respondents with higher quiz scores were more likely to agree to limit hydroelectric dams to promote water quality and to limit dams to promote water quality and habitat. As previously discussed, those with higher quiz scores were more likely to have an opinion on this tradeoff than those respondents with lower quiz scores. The quiz did not have a significant effect for the rural solar farm tradeoff, but did have a significant and positive effect for reducing the use of water intensive plants to increase safe drinking water. For the familiarity indicator, those who considered themselves less informed agreed to limiting hydroelectric dams for water quality, were less likely to agree with limiting the expansion of rural solar farms and more likely to agree with limiting solar expansion for agriculture, and also agreed to reduce the use of water intensive plants to increase access to safe water. Clearly, there is no discernable pattern of the impact of the knowledge indicators on the three FEW tradeoff issues included in this study. 
The final sets of variables included in the analyses were the environmental values and beliefs indicators. The analyses found that the measure of NEP employed in this study was significant in five of the models, and the climate change indicator was significant in five of the six models presented. Clearly both of these variables were the most influential in predicting FEW tradeoff preferences. However, the pattern of impact was not always as expected. For the energy-water tradeoff analyses displayed in Table 5, those respondents with higher NEP scores and who believed in human-caused global warming were less likely to agree with developing dams and more likely to agree with limiting dams when compared with respondents with lower NEP scores and who were non-believers in human-caused climate change. There is a clear preference for water quality over energy in this tradeoff, as might be expected for those concerned with the environment. The tradeoff concerning rural solar farm development versus protection of agricultural lands is more complicated. As might be expected, those respondents who believe in human-caused climate change were significantly more likely than non-believers to agree with expanding rural solar farms and less likely to agree with limiting rural solar farms for agriculture. However, those respondents with higher NEP scores were less likely to agree with expanding rural solar farms than respondents with lower NEP scores. Perhaps, in part, there is an underlying concern for the loss of food production, or perhaps this tradeoff poses a choice that many have not thought through. The ongoing debate in the Oregon context discussed earlier has divided the environmental community as well as the agricultural community, which may be driving the survey results here [44].

For the third tradeoff between increasing the use of water intensive plants to feed a growing population versus reducing water intensive plants for access to safe drinking water and sanitation, the NEP and climate change variables had similar effects that would be expected from those with stronger environmental values. More specifically, those respondents with higher NEP scores and who believed in human-caused climate change, agreed with the tradeoff of reducing the use of water intensive plants to increase access to safe drinking water and sanitation versus disagreeing with increasing the use of water intensive plants (e.g., rice) to feed a growing population.

\section{Conclusions}

As discussed in the beginning of the paper, the three western states of California, Oregon and Washington have been active participants in the 2013 Pacific Coast Action Plan on Climate and Energy. These three states are host to numerous FEW controversies; each state has a history of environmental concerns and have sizeable environmental movements; each state has extensive agricultural sectors, wherein they have experienced drought and water quality issues, and have experience with carbon-based (e.g., coal and gas), non-carbon-based (e.g., renewables, hydroelectric) energy production for the power grid. The state of Idaho was included in the study as a neighboring state that has not been actively promoting climate change mitigation policies, but nonetheless has also experienced drought and water quality issues, has a large agricultural sector, and is also experiencing the consequences of climate change that will exacerbate FEW tradeoff issues. The survey data analyses revealed that values and beliefs_-including climate change beliefs and most importantly the NEP-play a role in predicting public preferences concerning FEW tradeoffs, which is consistent with VBN Theory and other studies that examine FEW policy preferences in isolation from one another $[15,17,19,20]$.

This study builds on the Portney et al. [3] study by, first, examining FEW tradeoff preferences, and second, by including the NEP as a measure of environmental values. A main finding from Portney et al. is that people's knowledge of the nexus will lead to greater levels of support for policies designed to mitigate nexus challenges. The study presented here found that the knowledge indicators utilized were not good predictors of policy preferences concerning FEW tradeoffs. However, when used to examine specific policies in food, water and energy separately, that were also included in the survey, they showed more robust results, which will be examined in future papers using the survey results. Our findings do make a contribution to knowledge by suggesting that it is important to be aware of people's values and beliefs in addition to their knowledge when developing policies for the FEW 
nexus. In addition, this research could serve as a basis for additional research that could identify "best practices" for engaging the public in such complex issues as the FEW nexus [46].

Our research has some limitations, specifically because it is a regional study with relatively small state samples and lower response rates compared to the national Portney et al. study. In addition, many respondents were "neutral" concerning the FEW tradeoffs, potentially indicating issues with question wording or other concerns, or a lack of public discourse on the topic (the frequencies for the familiarity variable may indicate the latter). Future research could focus on questions that pertain to actual FEW policy tradeoffs instead of hypothetical tradeoffs. For example, the Klamath Basin controversy on California's and Oregon's border would be a good case study, as it is fraught with water quality and quantity issues that compete with fisheries, irrigated agriculture, and energy production issues. In addition, a multi-method research approach could offer more in-depth analysis into personal environmental values and FEW preferences, specifically integrating interviews into the research. Finally, the authors recognize that this study presents a snapshot providing broad insights into FEW conservations in the home. A more detailed research project would delve more deeply into trade-offs, constraints and behaviors.

Author Contributions: Conceptualization, B.S.S., E.A.W., R.L.W.; Methodology, B.S.S., E.A.W., R.L.W.; Analyses, B.S.S., R.L.W.

Funding: This research received no external funding. The survey was funded by the Oregon Policy Analysis Laboratory, School of Public Policy, Oregon State University (U.S.A.)

Acknowledgments: The authors thank the graduate student survey research team of Warda Ajaz, Allison Daniel, Najam uz Zehra Gardezi, Patricia T. Fernandez-Guajardo, Rebecca Langer, Heather Mae Moline, Gregory J. Stelmach, Maria Dolores Vazquez Rascon and Benjamin Wickizer.

Conflicts of Interest: The authors declare no conflict of interest.

\section{References}

1. Barik, B.; Ghosh, S.; Sahanna, A.S.; Pathak, A.; Sekhar, M. Water-food-energy Nexus with changing agricultural scenarios in India during recent decades. Hydrol. Earth Syst. Sci. 2017, 21, 3041-3060. [CrossRef]

2. O'Riordan, J.; Sandford, R.W. The Climate Nexus: Water, Food, Energy and Biodiversity in a Changing World; Rocky Mountain Books: British Columbia, BC, Canada, 2015.

3. Portney, K.E.; Hannibal; Goldsmith, B.C.; McGee, P.; Liu, X.; Vedlitz, A. Awareness of the food-water-energy nexus and public policy support in the United States: Public attitudes among the American people. Environ. Behav. 2017, 50, 1-26.

4. Ellis, G.; Barry, J.; Robinson, C. Many ways to say no, different ways to say yes: Applying Q-Methodology to understand public acceptance of wind farm proposals. J. Environ. Plan. Manag. 2007, 50, 517-551. [CrossRef]

5. Haggett, C. Understanding public responses to offshore wind power. En. Policy 2011, 39, 503-510. [CrossRef]

6. Leiserowitz, A.; Maibach, E.; Roser-Renouf, C. Climate Change in the American Mind: Americans' Climate Change Beliefs, Attitudes, Policy Preferences, and Actions; George Mason University: Center for Climate Change Communication, Fairfax, VA, USA, 2008.

7. Petrova, M.A. NIMBYism revisited: Public acceptance of wind energy in the United States. Wires Clim. Chang. 2013, 4, 575-601. [CrossRef]

8. United Nations. Department of Economic and Social Affairs. 2019. Available online: https://www.un.org/ development/desa/en/news/population/world-population-prospects-2017.html (accessed on 15 April 2019).

9. Fengler, W. Can Rapid Population Growth be Good for Economic Development? In Africa Can End Poverty; The World Bank: Washington, DC, USA, 2010.

10. European Report on Development. Confronting Scarcity: Managing Water, Energy and Land for Inclusive and Sustainable Growth; European Union: Brussells, Belgium, 2012.

11. World Wildlife Fund. Water Scarcity. Available online: https://www.worldwildlife.org/threats/water-scarcity (accessed on 15 April 2019).

12. Chavez, D.U.N. Highlights Profound Implication of Population Trends on Sustainable Development. U.N. News. April 2019. Available online: https://news.un.org/en/story/2019/04/1035841 (accessed on 31 August 2019). 
13. Stern, P.C.; Dietz, T.; Abel, T.D.; Guagnano, G.A.; Kalof, L. A Value-belief-norm theory of support for social movements: The case of environmentalism. Hum. Ecol. Rev. 1999, 6, 81-97.

14. Dunlap, R.E.; Van Liere, K.D.; Mertig, A.G.; Jones, R.E. Measuring endorsement of the New Ecological Paradigm: A revised NEP scale. J. Soc. Issues 2000, 56, 425-442. [CrossRef]

15. Lind, H.B.; Nordfjaern, T.; Jorgensen, S.H.; Rundmo, T. The Value-belief-norm theory, personal norms and sustainable travel mode choice in urban areas. J. Environ. Psychol. 2015, 44, 119-125. [CrossRef]

16. Sawitri, D.R.; Hadiyanto, H.; Hadi, S.P. Pro-environmental behavior from a Social Cognitive Theory perspective. Procedia Environ. Sci. 2015, 23, 27-33. [CrossRef]

17. Steel, B.S. Thinking globally and acting locally? Environmental attitudes, behavior and activism. J. Environ. Manag. 1996, 47, 27-36. [CrossRef]

18. Pierce, J.C.; Steel, B.S. Prospects for Alternative Energy Development in the U.S. West: Tilting at Windmills? Springer Press: Cham, Switzerland, 2017.

19. Arcury, T.A. Environmental attitude and environmental knowledge. Hum. Organ. 1990, 49, 300-304. [CrossRef]

20. Dietz, T.; Stern, P.C.; Guagnano, G.A. Social structural and social psychological bases of environmental concern. Environ. Behav. 1998, 30, 450-471. [CrossRef]

21. Jones, R.E.; Dunlap, R.E. The social basis of environmental concern: Have they changed over time? Rural Soc. 1992, 57, 28-47. [CrossRef]

22. Hines, J.M.; Hungerford, H.R.; Tomera, A.N. Analysis and synthesis of research on responsible environmental behavior. J. Environ. Educ. 1986, 18, 1-8. [CrossRef]

23. Casey, P.J.; Scott, K. Environmental concern and behavior in an Australian sample within an ecocentric-anthropocentric framework. Aust. J. Psychol. 2006, 58, 56-67. [CrossRef]

24. Howell, S.E.; Laska, S.B. The changing face of the environmental coalition: A research note. Environ. Behav. 1992, 24, 134-144. [CrossRef]

25. Xiao, C.; McCright, A.M. Environmental concern and sociodemographic variables: A study of statistical models. J. Environ. Educ. 2007, 38, 3-13. [CrossRef]

26. Bord, R.J.; O'Connor, R.E. The gender gap in environmental attitudes: The case of perceived vulnerability to risk. Soc. Sci. Q. 1997, 70, 586-593.

27. Pampel, F.C. The varied influence of SES on environmental concern. Soc. Sci. Q. 2014, 95, 57-75. [CrossRef]

28. O'Connor, R.E.; Bord, R.J.; Fisher, A. Risk perceptions, general environmental beliefs, and willingness to address climate change. Risk Anal. 1999, 19, 461-471. [CrossRef]

29. Mobley, C.; Vagias, W.M.; DeWard, S.L. Exploring Additional Determinants of Environmentally Responsible Behavior: The Influence of Environmental Literature and Environmental Attitudes. Environ. Behav. 2010, 42, 420-447. [CrossRef]

30. Milfont, T. The interplay between knowledge, perceived efficacy, and concern about global warming and climate change: A one-year longitudinal study. Risk Anal. 2012, 36, 1003-1020. [CrossRef] [PubMed]

31. Bronfman, N.C.; Cisternas, P.C.; Lopez-Vazquez, E.; de la Maza, C.; Oyanedel, J.C. Understanding attitudes and pro-environmental behaviors in a Chilean community. Sustainability 2015, 7, 14133-14152. [CrossRef]

32. Ntanos, S.; Kyriakopoulos, G.; Skordoulis, M.; Chalikias, M.; Arabatzis, G. An application of the New Environmental Paradigm (NEP) scale in a Greek context. Energies 2019, 12, 239. [CrossRef]

33. Poortinga, W.; Steg, L.; Vlek, C. Values, environmental concern, and environmental behavior: A study into household energy use. Environ. Behav. 2004, 36, 70-93. [CrossRef]

34. Salvaggio, M.; Futrell, R.; Batson, C.D.; Brents, B.G. Water scarcity in the desert metropolis: How environmental values, knowledge and concern affect Las Vegas residents' support for water conservation policy. J. Environ. Plan. Manag. 2014, 57, 588-611. [CrossRef]

35. Jackson-Smith, D.; Buttel, F. Social and ecological dimensions of the alternative-conventional agricultural paradigm scale. Rural Soc. 2003, 68, 513-530. [CrossRef]

36. Leiserowitz, A.; Maybach, E.; Roser-Renouf, N.; Smith, N. Global Warming's Six Americas; Yale Project on Climate Change: New Haven, CT, USA, 2011; Available online: https:/environment.yale.edu/climatecommunication/files/SixAmericasMay2011.pdf (accessed on 15 April 2019).

37. Leiserowitz, A. Climate change risk perception and policy preferences: The role of affect, imagery, and values. Clim. Chang. 2006, 77, 45-72. [CrossRef] 
38. McCright, A.M.; Dunlap, R.E. Cool dudes: The denial of climate change among conservative white males in the United States. Glob. Environ. Chang. 2011, 21, 1163-1172. [CrossRef]

39. Dillman, D.A. Mail and Internet Surveys: The Tailored Design Method, 2nd ed.; John Wiley and Sons: Hoboken, NJ, USA, 2007.

40. American Association for Public Opinion Research. Final Dispositions of Case Codes and Outcome Rates for Surveys. 2011. Available online: http://www.aapor.org/AM/Template.cfm?Section=Standard_Definitions2\& Template=/CM/ContentDisplay.cfm\&ContentID=3156 (accessed on 15 April 2019).

41. Messer, B.L.; Edwards, M.L.; Dillman, D.A. Determinants of Item Nonresponse to Web and Mail Respondents in Three Address-Based Mixed-Mode Surveys of the General Public, Technical Report 12-001; Social and Economic Sciences Research Center: Pullman, WA, USA; Washington State University: Washington, DC, USA, 2012; Available online: http://www.sesrc.wsu.edu/dillman/papersweb/2012.html (accessed on 15 June 2018).

42. Groves, R.M. Nonresponse rates and nonresponse bias in household surveys. Public Opin. Q. 2006, 70, 646-675. [CrossRef]

43. Lundmark, C. The Ecological Paradigm revisited: Anchoring the NEP scale in environmental ethics. Environ. Educ. Res. 2007, 13, 329-347. [CrossRef]

44. Liu, Q. WEF nexus cases from California with climate change implications. In Water-Energy-Food Nexus: Principles and Practices, Geophysical Monograph 229; Salam, P.A., Shrestha, S., Pandey, V.P., Anal, A.K., Eds.; John Wiley and Sons: New York, NY, USA, 2017.

45. Poehler, B. Oregon Could Effectively Ban Solar Farms, but First a Bunch of New Ones Will Be Built. Statesman Journal. 18 January 2019. Available online: https:/www.statesmanjournal.com/story/news/local/stayton/ 2019/01/18/oregon-looks-strict-rules-solar-arrays-high-value-farmland/2457949002/ (accessed on 15 April 2019).

46. Lackey, R.; Lach, D. Salmon 2100 Project: Alternative Futures for Pacific Salmon; American Fisheries Society: Bethesda, MD, USA, 2006.

47. Loures, L.; Panagopoulos, T.; Nunes, J.; Viegas, A. Learning from practice: Using case-study research towards post-industrial landscape redevelopment theory. In Sustainability Today; Brebbia, C.A., Ed.; WIT Press: South Hampton, UK, 2012.

48. Institute for Energy Research. California's Self-Inflicted Energy Shortage. 2016. Available online: https://www. instituteforenergyresearch.org/regulation/california-electricity-shortage-issues/ (accessed on 15 April 2019).

49. State of California. California drought. Available online: http://www.drought.ca.gov (accessed on 15 April 2019).

50. U.S. Drought Portal. Drought in Idaho. Available online: https://www.drought.gov/drought/states/idaho (accessed on 15 April 2019).

51. NOAA Fisheries. Reopening Rivers for Migratory Fish. Available online: https://www.fisheries.noaa.gov/ national/habitat-conservation/reopening-rivers-migratory-fish (accessed on 31 August 2019).

52. California Trout. Klamath Dam Removal. Available online: https://caltrout.org/our-work/steelhead-salmon/ klamath-dam-removal/ (accessed on 31 August 2019).

53. Steel, B.S. Saving wild salmon: Moving from symbolic politics to effective policy. In Salmon 2100 Project: Alternative Futures for Pacific Salmon; Lackey, R., Lach, D., Eds.; American Fisheries Society: Bethesda, MD, USA, 2006.

(C) 2019 by the authors. Licensee MDPI, Basel, Switzerland. This article is an open access article distributed under the terms and conditions of the Creative Commons Attribution (CC BY) license (http://creativecommons.org/licenses/by/4.0/). 